\title{
Gold-catalyzed glycosidation for the synthesis of trisaccharides by applying the armed-disarmed strategy
}

\author{
Abhijeet K. Kayastha and Srinivas Hotha*
}

\author{
Full Research Paper \\ Address: \\ Department of Chemistry, Indian Institute of Science Research and \\ Education, Pune-411 008, India \\ Email: \\ Srinivas Hotha* - s.hotha@iiserpune.ac.in \\ * Corresponding author \\ Keywords: \\ alkynes; armed-disarmed effect; glycosidation; gold
}

Open Access

\author{
Beilstein J. Org. Chem. 2013, 9, 2147-2155. \\ doi:10.3762/bjoc. 9.252 \\ Received: 29 July 2013 \\ Accepted: 27 September 2013 \\ Published: 18 October 2013

\begin{abstract}
This article is part of the Thematic Series "Gold catalysis for organic synthesis II" and is dedicated to Prof. M. Periasamy, University of Hyderabad on the occasion of his $60^{\text {th }}$ birthday.
\end{abstract} \\ Guest Editor: F. D. Toste
}

(c) 2013 Kayastha and Hotha; licensee Beilstein-Institut. License and terms: see end of document.

\begin{abstract}
The synthesis of oligosaccharides is still a challenging task as there is no universal glycosyl donor for the synthesis of all oligosaccharides. The gold catalysis for glycosidation reactions, in which alkynylated glycosides are used, has emerged as one of the versatile options in this regard. A cleavage of the interglycosidic bond that was thought to be due to the higher reaction temperature and the acidic medium was observed during the synthesis of trisaccharides. In addition, a very little percentage of deprotection of benzyl protecting groups at the C-6 position was observed and no deprotection of benzyl ethers in aliphatic molecules was noticed. In order to overcome this fact, a collection of leaving groups that contain an alkynyl moiety were screened. It was found that 1-ethynylcyclohexanyl (Ech) glycosides are suitable for carrying out the glycosidation at $25{ }^{\circ} \mathrm{C}$ in the presence of 5 mol $\%$ each of $\mathrm{AuCl}_{3}$ and $\mathrm{AgSbF}_{6}$. Subsequently, Ech-glycosides were observed to be suitable for the synthesis of trisaccharides under gold catalysis conditions.
\end{abstract}

\section{Introduction}

Observations that gold(III) has a great affinity for alkynes placed the chemistry of gold in an enviable situation that culminated into the total synthesis of several natural products, in which gold-mediated reactions are a key step [1-7]. Over the last two decades, chemistry with gold complexes has gained immense significance and thus been investigated for a variety of organic transformations in homogeneous and heterogeneous reaction media [8-14]. The use of gold catalysts in carbohydrate chemistry was first reported for the oxidation of alcohols [11-16]. However, until recently these catalysts were scarcely applied. Glycosidation is one of the key reactions in chemistry of carbohydrates, in which a nucleophile attaches to a saccharide to form a glycoside. In this process, the saccharide unit that is donating its glycon is called a glycosyl donor, 
whereas the saccharide that is accepting the glycon is referred to as glycosyl acceptor or aglycon. The synthesis of oligosaccharides is still a formidable task in spite of the development of various methods. There is still no universal glycosyl donor $[17,18]$, although the first glycoside was reported by Emil Fischer more than a century ago.

A series of observations in our laboratory led to the identification of a gold(III)-catalyzed glycosidation reaction that uses alkynyl glycosides as glycosyl donors [19-21]. The salient features of this glycosidation reaction are the requirement of a catalytic amount of gold salts, good reaction yields and mild reaction conditions [22]. The alkynophilicity of gold(III) salts has been found to be beneficial for the synthesis of 1,2-trans-glycosides [23], amino acid glycoconjugates [24], carbohydrate epitopes present on the cell surface of infectious bacteria [25] glycopolypeptides [26], glycopolyacrylates [27], and glycomimetics [28]. The remarkable reactivity and chemoselectivity have also attracted other groups to investigate gold catalysts for glycosidation [29-34].

Esters at the C-2 position of the saccharide are known to impede the glycoside formation whereas ethers (-OBn) facilitate the reaction. Fraser-Reid applied the terms disarmed to deactivated glycosyl donors [e.g., esters], and armed to the activated donors [e.g., ethers] $[35,36]$. During the synthesis of oligosaccharides by sequentially adding saccharides, armed-disarmed effects can effectively be utilized to tune the reactivity of the glycosyl donors by placing appropriate protecting groups at the C-2 position. Similar armed and disarmed effects were noticed during several gold-catalyzed glycosidations [22-28]. Propargyl mannopyranosides as glycosyl donors are ideal for investigating armed-disarmed strategies for the synthesis of oligosaccharides, because the gold-catalyzed glycosidation proceeds in a highly 1,2-trans diastereoselective fashion [22]. Accordingly, the armed mannosyl donor 1 was allowed to react with the disarmed aglycon 2 , under the standard conditions for a gold-catalyzed glycosidation $\left(\mathrm{AuBr}_{3}, \mathrm{CH}_{3} \mathrm{CN}, 70{ }^{\circ} \mathrm{C}\right)$, to observe the formation of disaccharide $\mathbf{3}$, in which the propargyl substitution is disarmed due to the presence of benzoates. Subsequently, the disarmed disaccharide $\mathbf{3}$ was transformed into an armed glycosyl donor 4 by simple saponification followed by etherification. The reaction between armed donor $\mathbf{4}$ and disarmed aglycon 2, which was carried out under the aforementioned conditions did not result in the formation of desired trisaccharide. Instead, disaccharide 3 (53\%) and 1,6-anhydro sugar $5(20 \%)$ were isolated as major products [37]. Interestingly, propargyl mannoside 1 (12\%) along with benzyl glycoside 6 and lactol 7 were noticed in 5\% and 4\% yield, respectively (Scheme 1).

The Brønsted acid ( $\mathrm{HBr}$ ) released from $\mathrm{AuBr}_{3}$ in the presence of the aglycon can protonate the exocyclic oxygen present in the
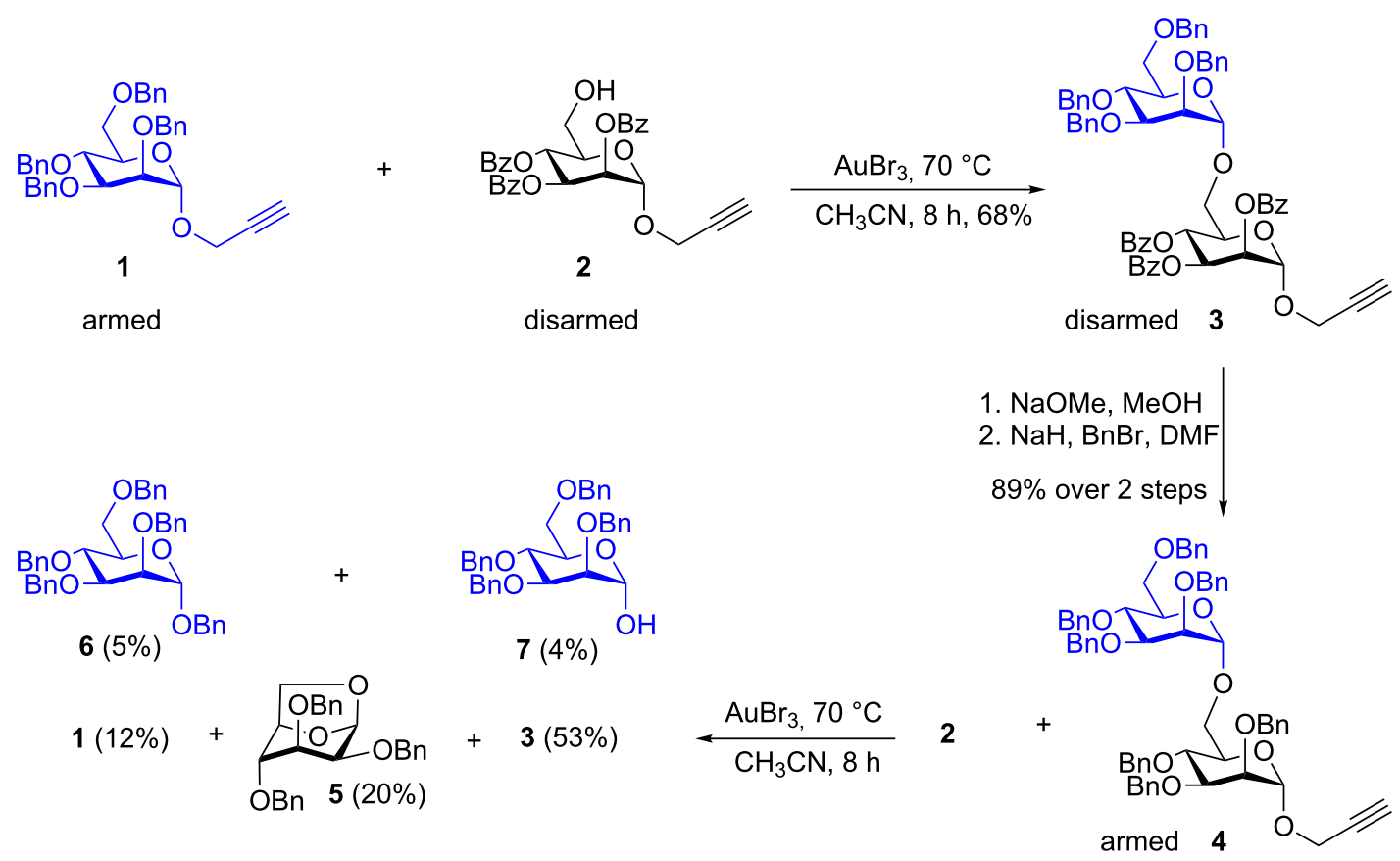
disaccharide 4. The protonation of the exocyclic oxygen and subsequent cleavage could give rise to oxocarbenium ion intermediates $\mathbf{A}$ and $\mathbf{B}$ as shown in Scheme 2. The formation of 1,6anhydro sugar $\mathbf{5}$ can be easily envisioned by the intramolecular attack of $\mathrm{C}-6-\mathrm{OH}$ on the intermediate $\mathbf{A}$. The surprising cleavage of the interglycosidic linkage leads to intermediate $\mathbf{B}$, which can be trapped by various nucleophiles that are present in the reaction mixture. The trapping of the intermediate $\mathbf{B}$ by propargyl alcohol gives propargyl mannoside 1 (12\%), the addition of $\mathrm{OH}^{-}$due to moisture results in lactol 7 (4\%), the addition of aglycon 2 gives rise to disaccharide 3 . The formation of benzyl mannoside 6 (5\%) can be explained by the attack of $\mathrm{BnO}^{-}$on the intermediate $\mathbf{B}$. The presence of $\mathrm{BnO}^{-}$ could be explained due to the hydrolysis of the primary benzyl ether.

\section{Results and Discussion}

In order to further understand the cleavage of the C- 6 benzyl ether, the model propargyl mannoside $\mathbf{8}$ was treated with $5 \mathrm{~mol} \%$ of $\mathrm{AuBr}_{3}$ under aforementioned conditions. LC-MS analysis of the reaction mixture showed the formation of anhydro sugar 4 (13\%), p-methylbenzyl mannoside 9 (9\%) and lactol $10(6 \%)$, which indicated the hydrolysis of the primary benzyl ether. The gold-catalyzed hydrolysis of benzyl ethers was not observed in the case of non-carbohydrate benzyl ether 11 (Scheme 3). For example, per- $O$-benzylated glycerol 11 did not show any benzyl deprotection, whereas the more acid-sensitive $p$-methoxybenzyl derivative $\mathbf{1 2}$ underwent deprotection of the $p$-methoxybenzyl moiety to give alcohol 13 with $88 \%$ yield. The deprotection of the $p$-methoxybenzyl moiety can be utilized for the one-pot synthesis of glycerol mannosides from mannosyl
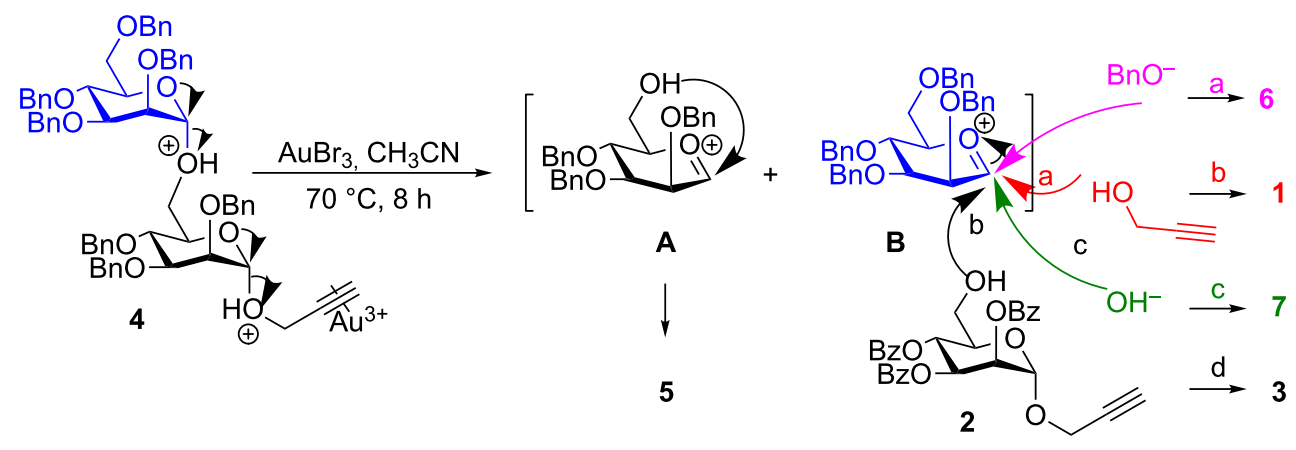

Scheme 2: Mechanistic rationale for the cleavage of the interglycosidic linkage.
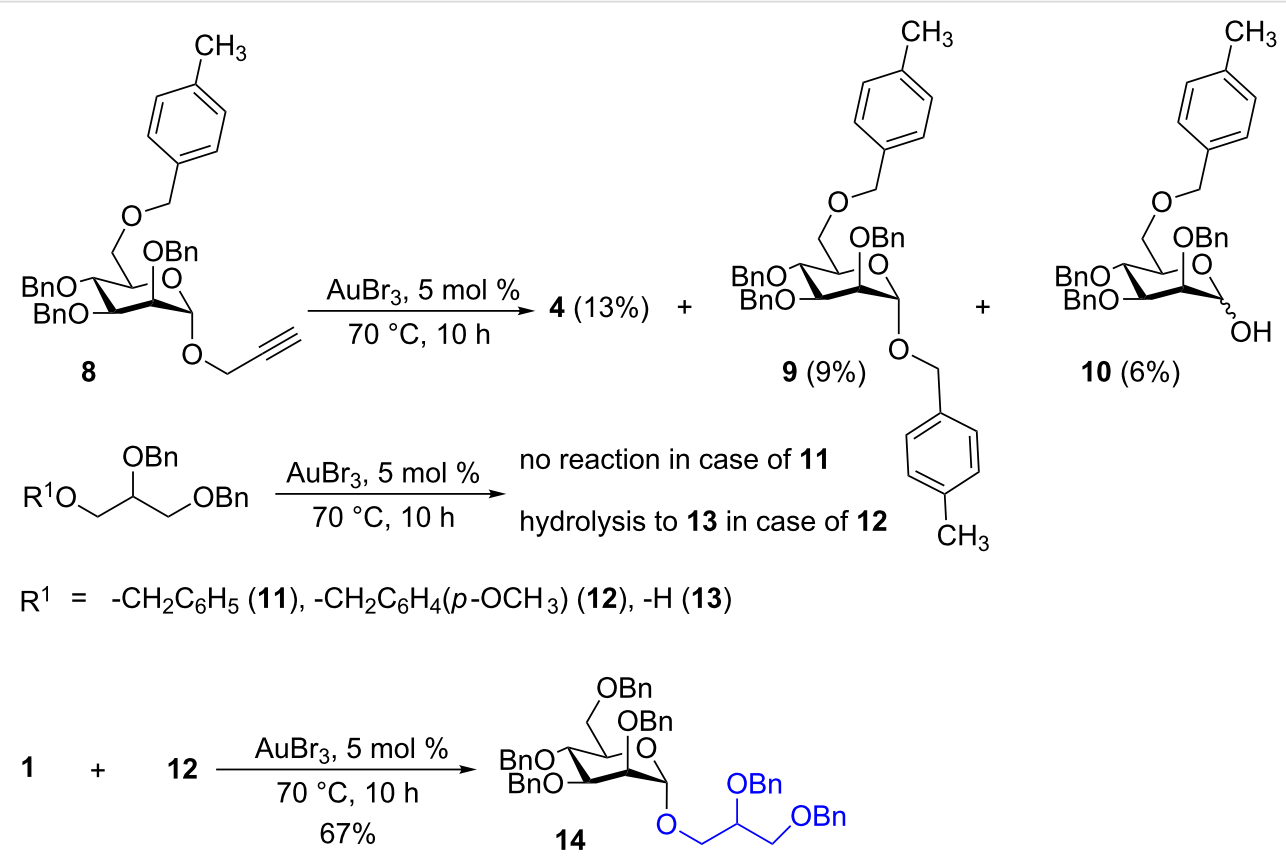

Scheme 3: C-6 Benzyl ether hydrolysis and synthesis of a glycerol mannoside. 
donor 1 and compound $\mathbf{1 2}$ in 67\% yield under gold-catalysis conditions (Scheme 3). Importantly, the hydrolysis of benzyl ethers was not observed when the gold catalysis reactions were performed at room temperature [23-28,38].

From the above observations, the high temperature $\left(70^{\circ} \mathrm{C}\right)$ of the glycosidation and the oxophilicity of gold salts were observed to be major impediments for the synthesis of oligo- saccharides. In order to overcome this problem, a systematic investigation of various leaving groups that bear an alkynyl moiety was carried out. The aim was to find a better leaving group, which would facilitate the glycosidation at ambient temperature. Accordingly, a panel of alkynylated glycosyl donors (15a-j) was synthesized and subjected to the glycosidation with three widely available gold salts, namely $\mathrm{AuBr}_{3}$, $\mathrm{AuCl}_{3}$ and $\mathrm{HAuCl}_{4}$, at $25^{\circ} \mathrm{C}$ for $12 \mathrm{~h}$ in acetonitirile (Table 1).

Table 1: Room temperature activation

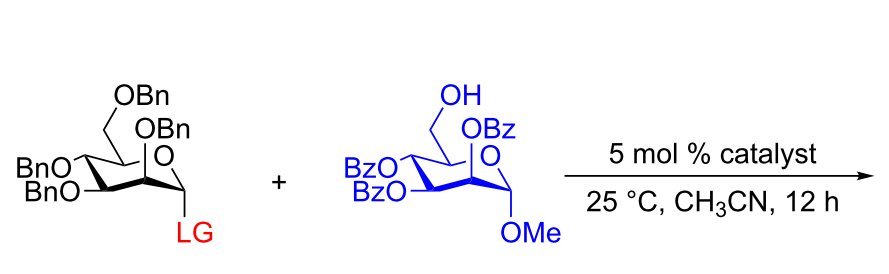

$15 a-1$

16

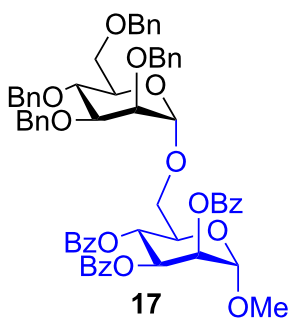

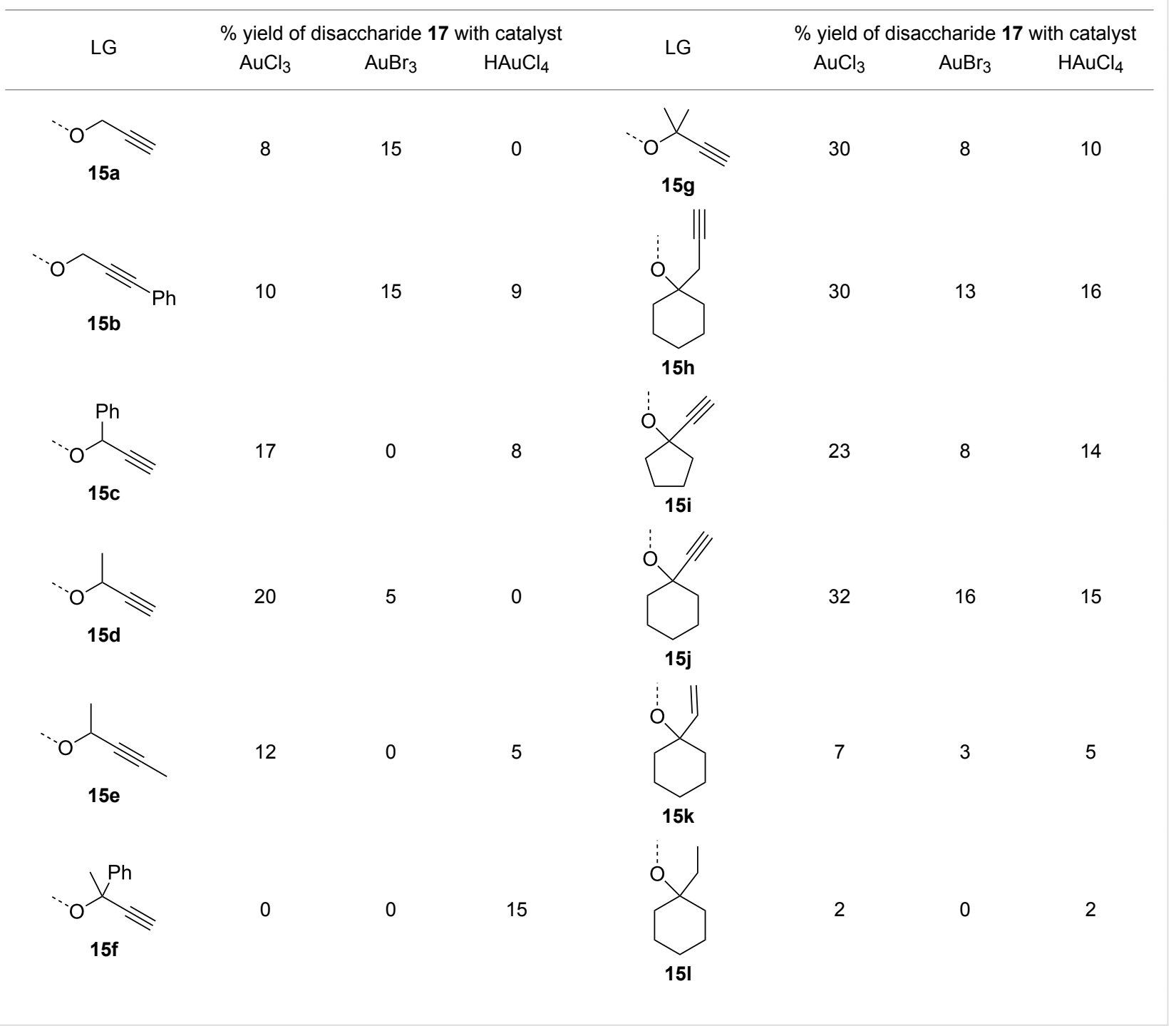


Substitutions at the terminal alkyne carbon $(\mathbf{1 5 b}, \mathbf{e})$ were not tolerated. The gem-dimethyl alkyne $\mathbf{1 5 g}$ showed a substantial improvement of the performance at $25{ }^{\circ} \mathrm{C}$ compared to the other alkynyl donors 15a-f (Table 1). However, the gem-dimethyl donor 15g was not preferred due to the shorter shelf life. The alicyclic derivatives $\mathbf{1 5 h}-\mathbf{j}$ gave comparable yields to $\mathbf{1 5 g}$ and were observed to be much more stable. Furthermore, $15 \mathrm{~h}$ needs to be prepared from cyclohexanone, while $\mathbf{1 5 i}$ is costly compared to $\mathbf{1 5} \mathbf{j}$. Thus, further studies were performed with $\mathbf{1 5} \mathbf{j}$ only. The alkyne moiety is really essential for the transglycosylation reaction as only very little formation of the desired product was noticed in the case of the donors $15 \mathbf{k}$ and $15 \mathbf{l}$. Subsequently, it was found that the addition of $5 \mathrm{~mol}_{\%}$ of $\mathrm{AgSbF}_{6}$ along with $\mathrm{AuCl}_{3}$ would increase the yield of disaccharide 17 to $96 \%$. However, the disaccharide formation was not observed with $\mathrm{AgSbF}_{6}$ alone [38].

In addition, armed mannosyl donor $\mathbf{1 5 j}$ reacted with aglycon $\mathbf{1 9}$ in the presence of $5 \mathrm{~mol} \%$ each of $\mathrm{AuCl}_{3} / \mathrm{AgSbF}_{6}$ in $\mathrm{CH}_{3} \mathrm{CN} /$ $\mathrm{CH}_{2} \mathrm{Cl}_{2}(1: 1)$ at $25^{\circ} \mathrm{C}$ for $4 \mathrm{~h}$ to give 1,2-trans menthyl mannoside 20. The leaving group 21 could be removed easily by applying high vacuum. Disarmed donors 18a and $\mathbf{1 8 b}$ failed to react with menthol (19) under aforementioned modified goldcatalysis conditions (Scheme 4).

The strong armed-disarmed effects that were observed for the Ech-donors at $25{ }^{\circ} \mathrm{C}$ encouraged us to continue the use of the armed-disarmed strategy for the trisaccharide synthesis. Accordingly, the armed mannosyldonor $\mathbf{1 5} \mathbf{j}$ was allowed to react with disarmed aglycon 22 in the presence of $\mathrm{AuCl}_{3}$ (5 mol \%)/ $\operatorname{AgSbF}_{6}(5 \mathrm{~mol} \%)$ in $\mathrm{CH}_{3} \mathrm{CN} / \mathrm{CH}_{2} \mathrm{Cl}_{2}(1: 1)$ at $25{ }^{\circ} \mathrm{C}$ for $4 \mathrm{~h}$ to obtain the disarmed disaccharide 23 in $85 \%$ yield. Further, the armed disaccharide $\mathbf{2 4}$ was synthesized from $\mathbf{2 3}$ by saponification followed by the etherification in $84 \%$ over two steps. The glycosylation between disaccharide $\mathbf{2 4}$ and disarmed aglycon 16 was performed under aforementioned conditions for a gold-catalyzed transglycosidation. Purification by conven- tional silica gel column chromatography enabled us to characterize the anticipated trisaccharide 25 (21\%) along with disaccharide $\mathbf{1 7}$ and anhydro sugar 5 (Scheme 5). In trisaccharide 25, three anomeric protons were noticed at $\delta 4.88(\mathrm{~d}, J=1.6 \mathrm{~Hz}$, $1 \mathrm{H}), 4.91(\mathrm{~d}, J=1.6 \mathrm{~Hz}, 1 \mathrm{H}), 5.61(\mathrm{dd}, J=1.6,3.2 \mathrm{~Hz}, 1 \mathrm{H})$ ppm. The ${ }^{13} \mathrm{C}$ NMR spectrum revealed that there are three mannose residues with 1,2-trans configuration as their anomeric carbon atoms were noticed at $\delta 98.1,98.2$ and $98.5 \mathrm{ppm}$ and the molecular weight was found to be $1483.586\left([\mathrm{M}+23]^{+}\right.$for the $\mathrm{Na}$ adduct). The rest of the resonances in the spectrum were completely in agreement with the assigned structure of trisaccharide 25. Formation of disaccharide 17 (34\%) and anhydro sugar 5 (16\%) can be rationalized on the basis of an interglycosidic bond cleavage.

The hydrolysis of the interglycosidic bond during the goldcatalyzed transglycosidation reaction depends on the nature of interglycosidic linkage. Generally the glycosyl donors with axial hydroxy groups are considered to be more reactive than the glycosyl donors without axial hydroxy group. For example, $\beta$-D-glucose is less reactive than $\alpha$-D-glucose or $\alpha$-D-mannose. In order to verify the effect of the differences in reactivity on the cleavage of the interglycosidic bond, armed disaccharide $\mathbf{2 6}$ was prepared and allowed to react with menthol (19) under aforementioned conditions for $6 \mathrm{~h}$ to obtain the anticipated menthyl glycoside (27) in 32\% yield. Similarly, the reactions with 4-penten-1-ol (28) and methyl 2,3,4-tri- $O$ benzyl $\alpha$-D-glucopyranoside (30) gave the corresponding transglycosides 29 and 31 in $37 \%$ and $23 \%$ yield, respectively (Scheme 6).

Finally, the gold-catalyzed transglycosidation reaction between disaccharide 32 and aglycon 16 gave the corresponding trisaccharide 33 in $76 \%$ yield. A cleavage of the interglycosidic bond was not observed, which shows the importance of the protecting groups in gold-catalyzed glycosidation reactions (Scheme 7).

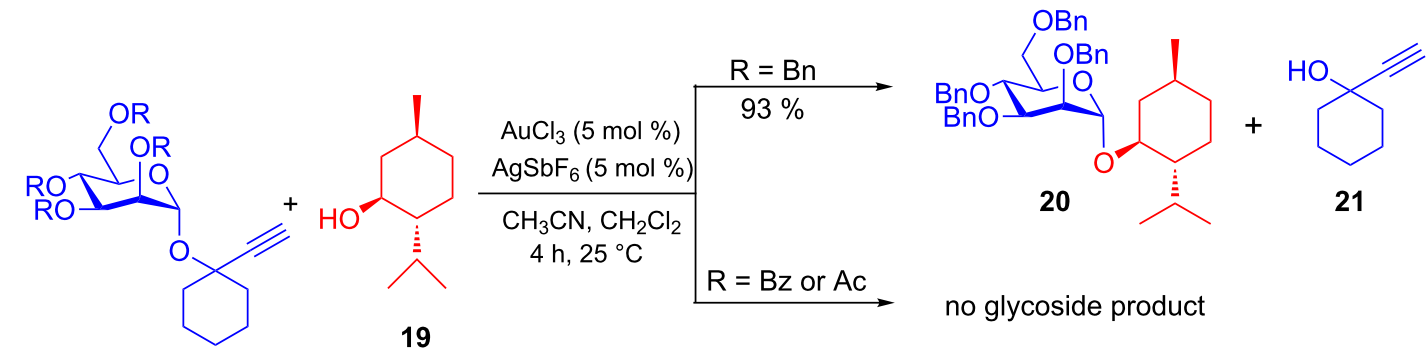

$R=B n(15 j), B z(18 a), A c(18 b)$ 

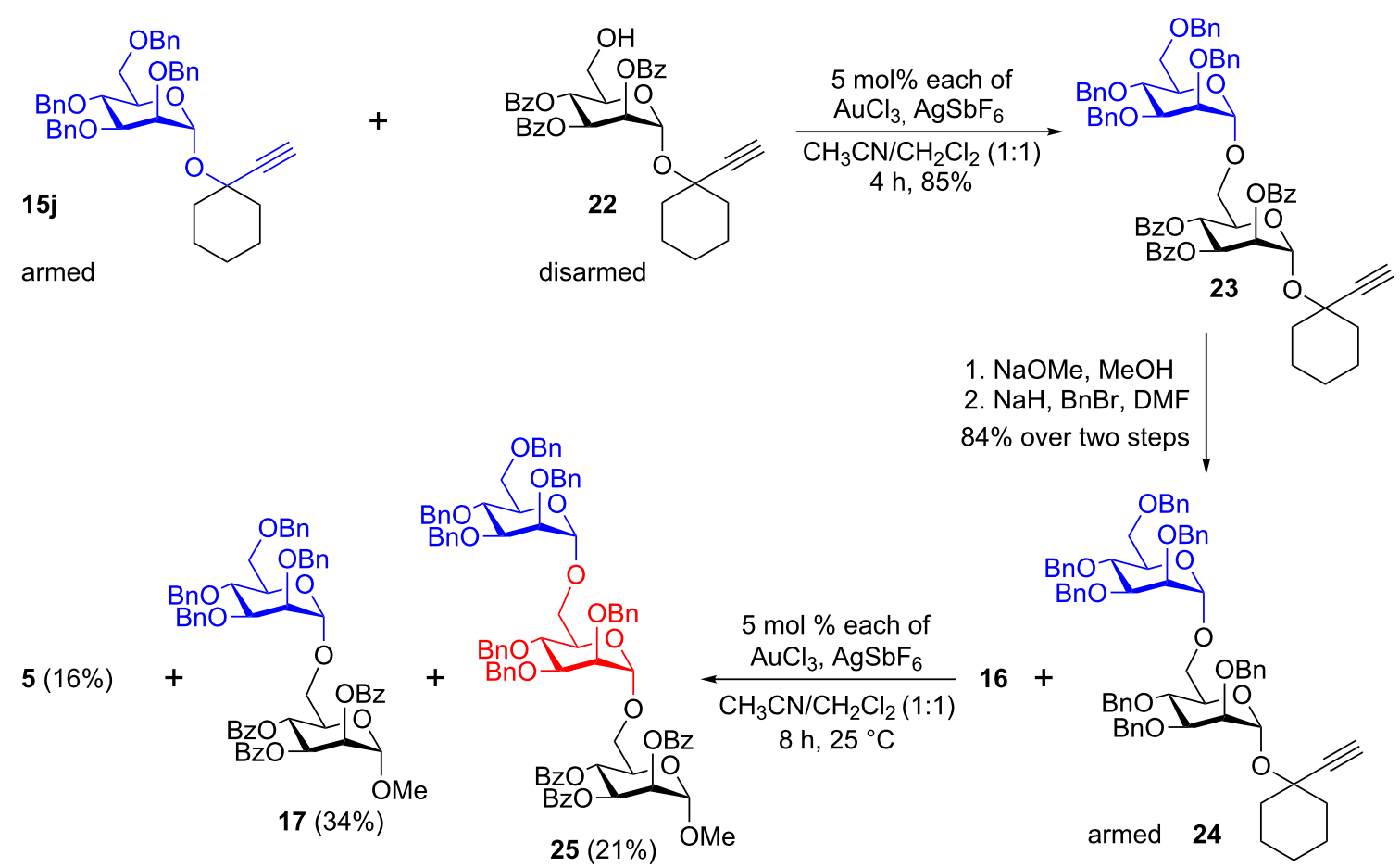

Scheme 5: Gold-catalyzed glycosidation at ambient temperature for the synthesis of trimannoside 25.

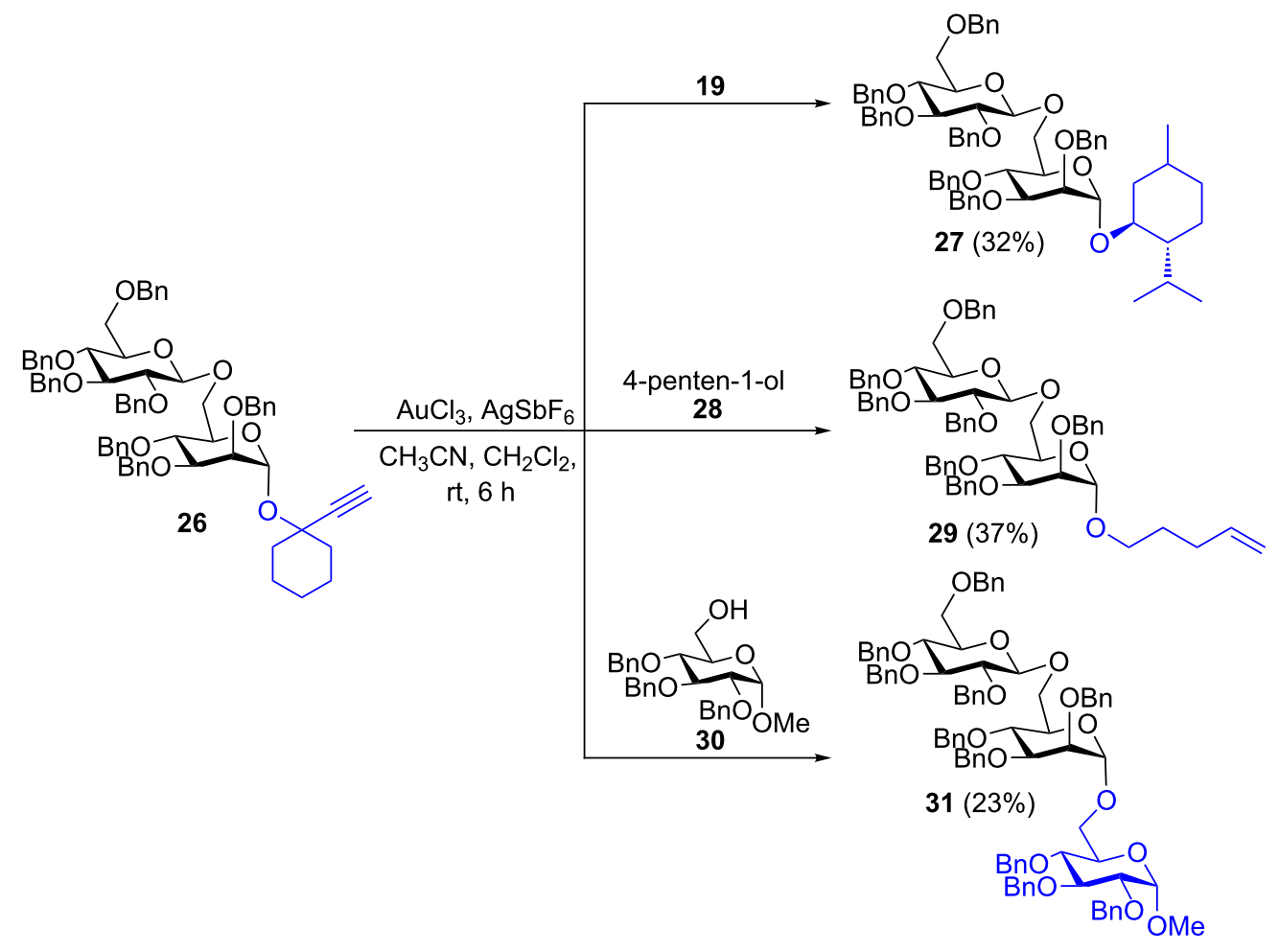

Scheme 6: Gold-catalyzed glycosidation at ambient temperature for the synthesis of higher saccharides. 


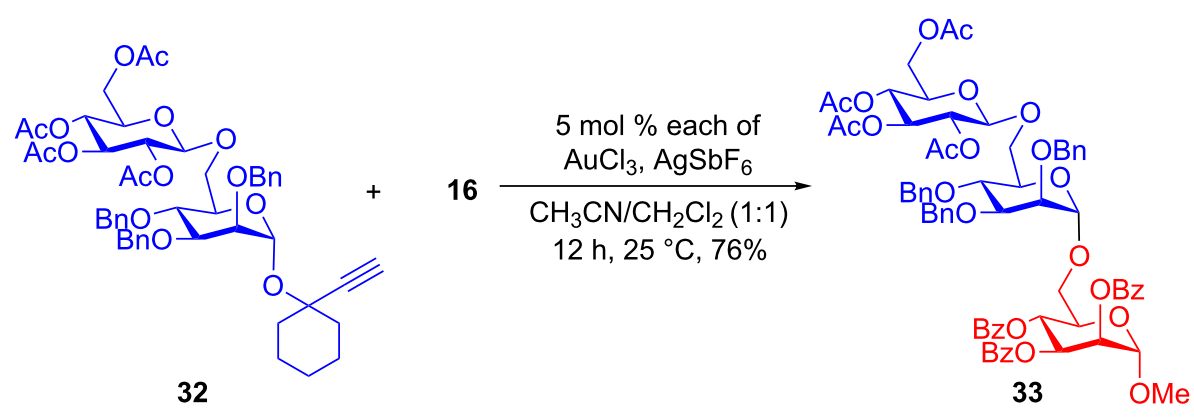

Scheme 7: Gold-catalyzed glycosidation for synthesis of higher saccharides.

\section{Conclusion}

In conclusion, the armed-disarmed effect in propargyl glycosides in the presence of a catalytic amount of gold salts is studied. The high temperature of the glycosidation was found to be partially responsible for the cleavage of the interglycosidic bond along with side reactions like benzyl deprotection. These observations were then successfully applied for PMB deprotection and one-pot glycosidation. Subsequent experiments proved the significance of the alkyne moiety. It was also observed that the addition of the silver salt $\mathrm{AgSbF}_{6}$ during the gold-mediated transglycosidation reaction helps in reducing the reaction temperature to $25^{\circ} \mathrm{C}$. This was successfully utilized for activating 1-ethynylcyclohexanyl donors at $25^{\circ} \mathrm{C}$. Trisaccharides were synthesized under identified conditions in moderate yields.

\section{Experimental}

All the reactions were performed under argon atmosphere. Products obtained as solids or syrups were dried under high vacuum. Gold and silver salts were purchased from SigmaAldrich. Analytical thin-layer chromatography was performed on pre-coated Merck silica plates ( $\mathrm{F}_{254}, 0.25 \mathrm{~mm}$ thickness); compounds were visualized by UV light or by staining with anisaldehyde spray. Optical rotations were measured on a JASCO P-1020 or Rudolph polarimeter. NMR spectra were recorded either on a Bruker AC 200, AV 400, AV 500 or JEOL ECX 400 or Bruker Avance 500 with $\mathrm{CDCl}_{3}$ as the solvent and tetramethylsilane as internal standard. High resolution mass spectroscopy (HRMS) was performed on ABI-MALDI-TOF using $\mathrm{TiO}_{2}$ as the solid matrix.

\section{Compound characterization data}

Characterization data for compound 15j [38]: $[\alpha]_{\mathrm{D}}{ }^{25}+28.2$ $\left(\mathrm{CHCl}_{3}, c 1.00\right) ;{ }^{1} \mathrm{H} \mathrm{NMR}\left(200.13 \mathrm{MHz}, \mathrm{CDCl}_{3}\right) \delta 1.10-2.15$ (m, 10H), $2.40(\mathrm{~s}, 1 \mathrm{H}), 3.65-4.12(\mathrm{~m}, 6 \mathrm{H}), 4.59(\mathrm{~s}, 2 \mathrm{H}), 4.60$ (ABq, $J=12.6 \mathrm{~Hz}, 2 \mathrm{H}), 4.71(\mathrm{ABq}, J=10.6 \mathrm{~Hz}, 2 \mathrm{H}), 4.76$ (s, $2 \mathrm{H}), 5.56(\mathrm{~d}, J=1.8 \mathrm{~Hz}, 1 \mathrm{H}), 7.13-7.42(\mathrm{~m}, 20 \mathrm{H}) ;{ }^{13} \mathrm{C} \mathrm{NMR}$ $\left(50.32 \mathrm{MHz}, \mathrm{CDCl}_{3}\right) \delta 22.7,22.7,25.0,37.6,38.2,69.3,71.9$, $72.1,72.3,73.3,74.1,75.0,75.2,75.2,75.5,80.0,84.6,94.0$,
$127.3-128.3,138.4,138.5,138.5,138.5$; HRMS (MALDI-TOF, $m / z$ ): $[\mathrm{M}+\mathrm{Na}]^{+}$calcd for $\mathrm{C}_{42} \mathrm{H}_{46} \mathrm{NaO}_{6}$, 669.3192; found, 669.3173.

Characterization data for compound 25: $[\alpha]_{\mathrm{D}}{ }^{25}-10.6\left(\mathrm{CHCl}_{3}, c\right.$ 1.00); ${ }^{1} \mathrm{H}$ NMR (500.13 MHz, $\left.\mathrm{CDCl}_{3}\right) \delta 3.42$ (s, 3H), 3.51-3.69 $(\mathrm{m}, 8 \mathrm{H}), 3.80(\mathrm{dd}, J=3.9,11.6 \mathrm{~Hz}, 1 \mathrm{H}), 3.84-3.88(\mathrm{~m}, 4 \mathrm{H})$, $3.95(\mathrm{dt}, J=9.4,25.7 \mathrm{~Hz}, 2 \mathrm{H}), 4.14(\mathrm{dt}, J=4.2,9.6 \mathrm{~Hz}, 1 \mathrm{H})$, $4.35-4.62(\mathrm{~m}, 8 \mathrm{H}), 4.41$ (ABq, $J=11.0 \mathrm{~Hz}, 2 \mathrm{H}), 4.61(\mathrm{~s}, 2 \mathrm{H})$, $4.84(\mathrm{ABq}, J=11.0 \mathrm{~Hz}, 2 \mathrm{H}), 4.88(\mathrm{~d}, J=1.5 \mathrm{~Hz}, 1 \mathrm{H}), 4.90$ (d, $J=1.5 \mathrm{~Hz}, 1 \mathrm{H}), 5.03(\mathrm{t}, J=10.0 \mathrm{~Hz}, 1 \mathrm{H}), 5.06(\mathrm{~d}, J=1.3 \mathrm{~Hz}$, $1 \mathrm{H}), 5.84(\mathrm{dd}, J=3.3,10.2 \mathrm{~Hz}, 1 \mathrm{H}), 7.11-7.51(\mathrm{~m}, 44 \mathrm{H})$, 7.81-8.08 (m, 6H); ${ }^{13} \mathrm{C}$ NMR $\left(125.76 \mathrm{MHz}, \mathrm{CDCl}_{3}\right) \delta 55.4$, 65.6, 66.6, 69.0, 69.1, 69.8, 70.6, 71.3, 71.7, 71.7, 71.7, 71.7, $72.2,72.7,73.2,74.2,74.6,74.8,74.9,74.9,75.0,79.2,80.2$, 98.1, 98.2, 98.4, 127.2-129.8, 133.1, 133.3, 133.5, 138.3, 138.3, 138.4, 138.4, 138.6, 138.6, 138.7, 165.3, 165.4, 165.5; HRMS (MALDI-TOF, $m / z$ ): $[\mathrm{M}+\mathrm{Na}]^{+}$calcd for $\mathrm{C}_{89} \mathrm{H}_{88} \mathrm{NaO}_{19}$, 1483.5818; found, 1483.5837 .

Characterization data for compound 29: $[\alpha]_{\mathrm{D}}{ }^{25} 18.4\left(\mathrm{CHCl}_{3}, c\right.$ 1.00); ${ }^{1} \mathrm{H}$ NMR (399.78 MHz, $\left.\mathrm{CDCl}_{3}\right) \delta 1.54(\mathrm{t}, J=7.2 \mathrm{~Hz}$, $2 \mathrm{H}), 1.59(\mathrm{~s}, 2 \mathrm{H}), 1.99(\mathrm{~m}, 2 \mathrm{H}), 3.26-3.98(\mathrm{~m}, 12 \mathrm{H}), 4.25-5.06$ $(\mathrm{m}, 18 \mathrm{H}), 5.73(\mathrm{~m}, 1 \mathrm{H}), 7.15-7.37(\mathrm{~m}, 35 \mathrm{H}) ;{ }^{13} \mathrm{C}$ NMR $(100.53$ $\left.\mathrm{MHz}, \mathrm{CDCl}_{3}\right) \delta 28.4,30.2,66.8,68.9,69.0,71.3,72.0,72.6$, 73.4, 74.7, 74.7, 74.9, 74.9, 74.9, 75.0, 75.7, 77.8, 80.2, 82.0, 84.6, 97.7, 104.0, 114.8, 126.9-128.5, 137.9, 138.1, 138.2, 138.3, 138.5, 138.5, 138.6; HRMS (MALDI-TOF, $\mathrm{m} / \mathrm{z}$ ): $[\mathrm{M}+\mathrm{Na}]^{+}$calcd for $\mathrm{C}_{66} \mathrm{H}_{72} \mathrm{NaO}_{11}, 1063.4972$; found, 1063.4994 .

Characterization data for compound 31: $[\alpha]_{\mathrm{D}}{ }^{25}+23.1\left(\mathrm{CHCl}_{3}, c\right.$ 1.00); ${ }^{1} \mathrm{H}$ NMR (399.78 MHz, $\mathrm{CDCl}_{3}$ ) $\delta 3.17$ (s, 3H), 3.25-3.94 $(\mathrm{m}, 17 \mathrm{H}), 4.11(\mathrm{dd}, J=1.8,9.1 \mathrm{~Hz}, 1 \mathrm{H}), 4.24-4.96(\mathrm{~m}, 23 \mathrm{H})$, 7.04-7.32 (m, 50H); $\left.{ }^{13} \mathrm{C} \mathrm{NMR} \mathrm{(100.53} \mathrm{MHz,} \mathrm{CDCl}_{3}\right) \delta 55.0$, 65.6, 68.7, 69.0, 69.8, 71.3, 71.8, 72.5, 73.2, 73.4, 73.4, 74.5, $74.6,74.7,74.8,74.9,74.9,74.9,74.9,77.5,77.8,79.5,79.9$, 82.0, 82.0, 84.6, 97.6, 98.1, 104.0, 127.3-128.4, 138.1, 138.1, 
138.1, 138.2, 138.3, 138.3, 138.5, 138.6, 138.6, 138.7; HRMS (MALDI-TOF, $m / z$ ): $[\mathrm{M}+\mathrm{Na}]^{+}$calcd for $\mathrm{C}_{89} \mathrm{H}_{94} \mathrm{NaO}_{16}$ 1441.6440; found, 1441.6457 .

Characterization data for compound 33: $[\alpha]_{\mathrm{D}}{ }^{25}-63.8\left(\mathrm{CHCl}_{3}, c\right.$ 1.00); ${ }^{1} \mathrm{H}$ NMR (399.78 MHz, $\left.\mathrm{CDCl}_{3}\right) \delta 1.95$ (s, 3H), 1.99 (s, $3 \mathrm{H}), 2.01(\mathrm{~s}, 3 \mathrm{H}), 2.02(\mathrm{~s}, 3 \mathrm{H}), 3.50-4.21(\mathrm{~m}, 13 \mathrm{H}), 4.33-4.37$ $(\mathrm{m}, 3 \mathrm{H}), 4.52(\mathrm{~d}, J=11.4 \mathrm{~Hz}, 1 \mathrm{H}), 4.58(\mathrm{~s}, 2 \mathrm{H}), 4.90-4.96(\mathrm{~m}$, $3 \mathrm{H}), 5.01(\mathrm{t}, J=9.8 \mathrm{~Hz}, 1 \mathrm{H}), 5.03(\mathrm{t}, J=10.1 \mathrm{~Hz}, 1 \mathrm{H}), 5.13(\mathrm{t}$, $J=9.4 \mathrm{~Hz}, 1 \mathrm{H}), 5.63(\mathrm{dd}, J=1.8,3.2 \mathrm{~Hz}, 1 \mathrm{H}), 5.84(\mathrm{dd}$, $J=3.2,9.8 \mathrm{~Hz}, 1 \mathrm{H}), 7.23-7.54(\mathrm{~m}, 24 \mathrm{H}), 7.81-8.11(\mathrm{~m}, 6 \mathrm{H})$; ${ }^{13} \mathrm{C}$ NMR $\left(100.53 \mathrm{MHz}, \mathrm{CDCl}_{3}\right) \delta 20.5,20.5,20.6,20.6,55.4$, $61.8,66.6,67.8,68.3,68.7,69.1,69.9,70.5,71.0,71.1,71.5$, $71.5,72.5,72.8,74.4,74.6,74.8,80.1,98.0,98.4,100.9$, $127.4-129.8,133.0,133.3,133.4,138.2,138.3,138.5,165.3$, $165.4,165.5,169.0,169.4,170.3,170.6$; HRMS (MALDI-TOF, $m / z$ ): $[\mathrm{M}+\mathrm{Na}]^{+}$calcd for $\mathrm{C}_{69} \mathrm{H}_{72} \mathrm{NaO}_{23}$, 1291.4362; found, 1291.4377 .

\section{Supporting Information}

\section{Supporting Information File 1}

Detailed experimental data.

[http://www.beilstein-journals.org/bjoc/content/

supplementary/1860-5397-9-252-S1.pdf]

\section{Acknowledgements}

A. K. K. thanks for financial support from UGC, New Delhi and S. H. thanks DST, New Delhi for Swarnajayanti fellowship.

\section{References}

1. Ghosh, N.; Nayak, S.; Sahoo, A. K. J. Org. Chem. 2011, 76, 500-511. doi:10.1021/jo101995g

2. Trost, B. M.; Dong, G. Nature 2008, 456, 485-488. doi:10.1038/nature07543

3. Trost, B. M.; O’Boyle, B. M.; Hund, D. J. Am. Chem. Soc. 2009, 131, 15061-15074. doi:10.1021/ja906056v

4. Fang, C.; Pang, Y.; Forsyth, C. J. Org. Lett. 2010, 12, 4528-4531. doi:10.1021/ol101833h

5. Tlais, S. F.; Dudley, G. B. Beilstein J. Org. Chem. 2011, 7, 570-577. doi:10.3762/bjoc.7.66

6. Benson, S.; Collin, M.-P.; Arlt, A.; Gabor, B.; Goddard, R.; Fürstner, A. Angew. Chem., Int. Ed. 2011, 50, 8739-8744. doi:10.1002/anie.201103270

7. Nakajima, R.; Ogino, T.; Yokoshima, S.; Fukuyama, T. J. Am. Chem. Soc. 2010, 132, 1236-1237. doi:10.1021/ja9103233

8. Herrmann, W. A.; Cornils, B. Angew. Chem., Int. Ed. 1997, 36, 1048-1067. doi:10.1002/anie.199710481

9. Bond, G. C.; Sermon, P. A.; Webb, G.; Buchanan, D. A.; Wells, P. B. J. Chem. Soc., Chem. Commun. 1973, 444b-445. doi:10.1039/C3973000444B
10. Hashmi, A. S. K.; Schwarz, L.; Choi, J.-H.; Frost, T. M. Angew. Chem., Int. Ed. 2000, 39, 2285-2288. doi:10.1002/1521-3773(20000703)39:13<2285::AID-ANIE2285>3.0.CO ;2-F

11. Haruta, M. Nature 2005, 437, 1098-1099. doi:10.1038/4371098a

12. Hutchings, G. J. Catal. Today 2005, 100, 55-61. doi:10.1016/j.cattod.2004.12.016

13. Haruta, M.; Kobayashi, T.; Sano, H.; Yamada, N. Chem. Lett. 1987, 16, 405-408. doi:10.1246/cl.1987.405

14. Hutchings, G. J. J. Catal. 1985, 96, 292-295. doi:10.1016/0021-9517(85)90383-5

15. Prati, L.; Rossi, M. J. Catal. 1998, 176, 552-560. doi:10.1006/jcat.1998.2078

16. Biella, S.; Prati, L.; Rossi, M. J. Catal. 2002, 206, 242-247. doi:10.1006/jcat.2001.3497

17. Paulsen, H. Angew. Chem. 1982, 94, 184-201. doi:10.1002/ange.19820940304

18. Paulsen, H. Angew. Chem., Int. Ed. Engl. 1982, 21, 155-173. doi:10.1002/anie.198201553

19. Maurya, S. K.; Hotha, S. Tetrahedron Lett. 2006, 47, 3307-3310. doi:10.1016/j.tetlet.2006.03.016

20. Kashyap, S.; Hotha, S. Tetrahedron Lett. 2006, 47, 2021-2023. doi:10.1016/j.tetlet.2006.01.048

21. Kashyap, S.; Vidadala, S. R.; Hotha, S. Tetrahedron Lett. 2007, 48, 8960-8962. doi:10.1016/j.tetlet.2007.10.144

22. Hotha, S.; Kashyap, S. J. Am. Chem. Soc. 2006, 128, 9620-9621. doi:10.1021/ja062425c

23. Sureshkumar, G.; Hotha, S. Tetrahedron Lett. 2007, 48, 6564-6568. doi:10.1016/j.tetlet.2007.07.015

24. Shaikh, A. Y.; Sureshkumar, G.; Pati, D.; Gupta, S. S.; Hotha, S. Org. Biomol. Chem. 2011, 9, 5951-5959. doi:10.1039/c1ob05056g

25. Sureshkumar, G.; Hotha, S. Glycoconjugate J. 2012, 29, 221-230. doi:10.1007/s10719-012-9400-7

26. Pati, D.; Shaikh, A. Y.; Hotha, S.; Gupta, S. S. Polym. Chem. 2011, 2, 805-811. doi:10.1039/c0py00412j

27. Thadke, S. A.; Kar, M.; Gupta, S. S.; Hotha, S. Carbohydr. Res. 2011, 346, 1511-1518. doi:10.1016/j.carres.2011.04.018

28. Vidadala, S. R.; Pimpalpalle, T. M.; Linker, T.; Hotha, S. Eur. J. Org. Chem. 2011, 2426-2430. doi:10.1002/ejoc.201100134

29. Mamidyala, S. K.; Finn, M. G. J. Org. Chem. 2009, 74, 8417-8420. doi:10.1021/jo901857x

30. Götze, S.; Fitzner, R.; Kunz, H. Synlett 2009, 3346-3348. doi:10.1055/s-0029-1218356

31. Li, Y.; Yang, Y.; Yu, B. Tetrahedron Lett. 2008, 49, 3604-3608. doi:10.1016/j.tetlet.2008.04.017

32. Li, Y.; Tang, P.; Chen, Y.; Yu, B. J. Org. Chem. 2008, 73, 4323-4325. doi:10.1021/j08003875

33. Yang, F.; Wang, Q.; Yu, B. Tetrahedron Lett. 2012, 53, 5231-5234. doi:10.1016/j.tetlet.2012.07.059

34. Adhikari, S.; Baryal, K. N.; Zhu, D.; Li, X.; Zhu, J. ACS Catal. 2013, 3, 57-60. doi:10.1021/cs300670k

35. Fraser-Reid, B.; Wu, Z.; Udodong, U. E.; Ottosso, H. J. Org. Chem. 1990, 55, 6068-6070. doi:10.1021/jo00312a004

36. Mootoo, D. R.; Konradsson, P.; Udodong, U.; Fraser-Reid, B. J. Am. Chem. Soc. 1988, 110, 5583-5584. doi:10.1021/ja00224a060

37. Kayastha, A. K.; Hotha, S. Tetrahedron Lett. 2010, 51, 5269-5272. doi:10.1016/j.tetlet.2010.07.157

38. Kayastha, A. K.; Hotha, S. Chem. Commun. 2012, 48, 7161-7163. doi:10.1039/c2cc32649c 


\section{License and Terms}

This is an Open Access article under the terms of the Creative Commons Attribution License

(http://creativecommons.org/licenses/by/2.0), which permits unrestricted use, distribution, and reproduction in any medium, provided the original work is properly cited.

The license is subject to the Beilstein Journal of Organic Chemistry terms and conditions:

(http://www.beilstein-journals.org/bjoc)

The definitive version of this article is the electronic one which can be found at:

doi:10.3762/bjoc. 9.252 